\title{
EKONOMI PADA MASA BANI UMAYYAH, ABBASIYAH DAN TURKI UTSMANI
}

\author{
Aninda Aprilia (90100118031) \\ anindaaprilia038@gmail.com
}

Perekonomian adalah merupakan salah satu terpenting dalam memperlancar proses pembangunan suatu Negara. Sebab merosotnya perekonomian suatu Negara akan terpengaruh terhadap proses pelaksanaan pembangunan yang akan di lakukan. Dalam kesempatan ini, kami akan membahas mengenai perkembangan ekonomi pada masa daulah abbasiyah dan daulah umayyah. Pada masa pemerintahan Abdul Malik, perkembangan perdagangan dan perekonomian, teraturnya pengelolaan pendapatan Negara yang di dukung oleh keamanan dan ketertiban yang terjamin telah membawa masyarakatnya pada tingkat kemakmuran. Realisasinya dapat kita liat dari hasil penerimaan pajak ( kharaj) di wilayah syam saja, tercatat 1.730 .000 dinar emas setahun. Kemakmuran masyarakat Bani Umayyah juga terlihat pada masa pemerintahannya telah naik ke taraf yang menakjubkan. Semua literatul yang ada pada kita sekarang ini menguatkan bahwa kemiskinan, kemelaratan, dan kepapaan telah dapat di atasi pada masa pemerintahan khalifah ini.(Huda 2020)

Secara historis, puncak keemasan Daulah Umayyah berada di zaman Khalifah Umar bin Abdul Aziz. Pada masa tersebut, khalifah mengeluarkan banyak kebijakan di bidang ekonomi sehingga kebijakan tersebut mampu mengeluarkan masyarakat dari kemiskinan. Sejarah mencatat bahwa pada masa umar II, para muzakki sulit menemukan para fakir dan miskin. Dia mampu meletakkan neraca keadilan bagi rakyat maupun keluarganya.( Hakam, 2002: 95). Sejarah tidak selalu manis, khalifah terakhir Bani Umayyah adalah Marwan al-Himar atau Marwan II, yang dikenal dengan sebutan Abu Abdul Malik. Dia diberi gelar al- Ja'di sebagai penisbatan kepada orang yang mengajari tata krama yang bernama al-Ja'ad bin Dirham. Sedangkan al-Himar (keledai) karena dia sangat sabar dalam menghadapi musuh-musuhnya yang memberontak. Pada masa Marwan II, Nasr bin Sayyar memerintah sebagai gubernur di Khurasan. Dia mempunyai beberapa kebijakan, khususnya kebijakan ekonomi yang menjadi salah satu penyebab munculnya berbagai pemberontakan (ROFIQO and RIZAL 2019)

Masalah kemiskinan masih terus menjadi perhatian hingga saat ini terutama di beberapa negara seperti Indonesia yang masih tergolong negara berkembang (developing nations).1 Kemiskinan 
merupakan persoalan laten di Indonesia. Pada sisi yang lain, upaya pemulihan ekonomi berjalan sangat lambat, sehingga dalam kenyataannya kemiskinan bertambah sangat memprihatinkan. Yang umumnya merupakan bagian kecil dalam masyarakat, ke kelompok miskin, yang umumnya merupakan bagian terbesar dalam masyarakat. Hal ini secara langsung akan meningkatkan permintaan barang dan jasa dari kelompok miskin, yang umumnya adalah kebutuhan dasar seperti pangan, sandang, dan papan. (Aqbar n.d.)

Rasulullah SAW dalam segala kata kata yang diucapkannya, segala tingkah laku yang diperbuatnya dan segala sikap yang diambilnya merupakan gambaran hidup terhadap pemikiran pendidikan Islam.(Rohman 2013)

Nabi Muhammad SAW. Membuat kebijakan Fiskal dan kebijakan moneter. Kebijakan fiskal diantaranya Peningkatan pendapatan Nasional dan tingkat partisipasi kerja, kebijakan Pajak, Anggaran, dan Kebijakan Fiskal Khusus. Sedangkan kebijakan moneter yaitu penggunaan mata uang dinar dan dirham. Namun yang lebih umum digunakan adalah dirham karena tentara Islam berhasil menaklukan hampir seluruh wilayah kekaisaran persia. Sementara itu, tidak semua wilayah kekaisaran romawi berhasil dikuasai tentara Islam.(Ibnuddin 2019)

Huda, Muhammad Nurul. 2020. "Sejarah Pemikiran Ekonomi Islam Pada Masa Daulah Bani Umayyah Dan Bani Abbasiyah.” 1(01): 94-105.

AZIDNI ROFIQO, and FITRA RIZAL. 2019. "Economic Policy in Umayyah Era (Policy Success of Umar Ii and Failure of Governor of Nasar Bin Sayyar in Marwan Ii Era 744750).” Al-Tsaqafa : Jurnal Ilmiah Peradaban Islam 16(2): 226-36.

Aqbar, Khaerul. "Kata Kunci : Zakat; Kebijakan; Umar Bin Khattab.”

Rohman, Abdul. 2013. “Konsep Pendidikan Islam Masa Rasulullah Dan Sahabat.” Al-Misbah 01(01): 108-19.

Ibnuddin. 2019. "Pemikiran Ekonomi Islam Pada Masa Nabi Muhammad.” Risalah Vol.5, No.(1): 51-61. 